\title{
PENTINGNYA LINGKUNGAN \\ DALAM PEMBELAJARAN BAHASA INDONESIA
}

\author{
Kartika Kencana/19016166
}

kencanakartika32@gmail.com

Lingkungan adalah suatu media di mana makhluk hidup tinggal, bertahan hidup, dan memiliki karakter serta fungsi yang khas terkait secara timbal balik dengan keberadaan makhluk hidup yang menempatinya, terutama manusia yang memiliki peranan yang lebih kompleks. Ira et al (2018) mengatakan bahwa antara manusia dan lingkungan hidupnya terdapat hubungan yang timbal balik. Manusia mempengaruhi lingkungan hidupnya, dan sebaliknya manusia dipengaruhi oleh lingkungan hidupnya dan tidak terpisahkan satu sama lain. Hal ini dikarenakan pengaruh lingkungan memang sangat besar terhadap kehidupan setiap orang. Berbagai macam hal dapat ditemui pada lingkungan, mulai dari pembelajaran hingga permasalahan. Menurut Sukma (2020) sebagai individu, manusia memiliki tanggung jawab untuk memecahkan masalah lingkungan. Salah satu bentuk upaya mengatasi permasalahan lingkungan tersebut adalah dengan pengetahuan yang benar dari semua faktor lingkungan untuk menjaga lingkungannya, dan semua itu dapat diperoleh melalui proses pendidikan.

Menurut Oemar Hamalik (2004:195) lingkungan (environment) sebagai dasar pengajaran adalah faktor kondisional yang mempengaruhi tingkah laku individu dan merupakan faktor belajar yang penting. Sehingga pemanfaatan lingkungan bisa dijadikan media dalam metode pembelajaran. Putri et al (2019) mengungkapkan bahwa dalam pembelajaran di lingkungan sekolah, pengajaran membaca harus memperoleh perhatian yang serius dari pendidik di Indonesia. Melalui pengajaran, pendidik mampu mengarahkan peserta didik dalam pembelajaran bahasa. Menurut Uyar dan Ensar (dalam Ramadhan et al, 2019) dengan menggunakan tema lingkungan dalam pembelajaran teks dapat memicu minat siswa dalam mempelajari bahasa dan secara berimplikasi dapat meningkatkan pengetahuan siswa tentang lingkungan hidup.

Ramadhan et al (2019) mengatakan bahwa pendidikan lingkungan penting untuk meningkatkan sikap dan kesadaran peserta didik terhadap lingkungan hidup. Ramadhan et al (2019) juga menyatakan pendidikan lingkungan mampu membantu siswa memikirkan kembali hubungan atau korelasi antara manusia dengan lingkungannya. Dengan adanya pembelajaran berbasis lingkungan ini, siswa akan lebih peka terhadap kondisi lingkungan. Lingkungan merupakan komponen yang sangat berpengaruh dalam melaksanakan aktifitas belajar mengajar, khususnya pada pembelajaran bahasa Indonesia. Pembelajaran bahasa Indonesia di kelas terkadang membuat siswa merasa bosan, bahkan dapat mengakibatkan motivasi belajar siswa menurun. Zulhafizh et al (2013) mengatakan bahwa jika sikap dan motivasi belajar siswa terhadap pelajaran bahasa Indonesia rendah, maka perlu dilakukan pembinaan dan peningkatan sikap dan motivasi belajar siswa terhadap pelajaran bahasa Indonesia. Oleh karena itu, saat siswa mengalami penurunan motivasi belajar, guru dapat mengajak siswa untuk memanfaatkan lingkungan sebagai media pembelajaran yang 
menyenangkan. Tidak hanya siswa, guru juga perlu berpikir kreatif dalam memanfaatkan lingkungan untuk dijadikan media pembelajaran. Guru merupakan fasilitator bagi siswanya. Hal ini sejalan dengan pernyataan Sukma (2012) dan Ramadhan et al (2019) yaitu guru berfungsi sebagai fasilitator dan manajer pembelajaran dalam proses pembelajaran.

Pembelajaran yang dilakukan di lingkungan akan meningkatkan kemampuan berpikir kreatif siswa, sehingga siswa dapat mengembangkan berbagai macam karya tulis. Atmazaki (dalam Wilda et al, 2014) menjelaskan bahwa diperlukan kemampuan berpikir kreatif dalam mengapresiasi karya sastra karena karya sastra itu sendiri adalah karya kreatif. Menurut Semi (dalam Ira et al, 2018) bahwa menulis merupakan suatu proses kreatif, ia harus mengalami suatu proses yang secara sadar dilalui dan secara sadar pula dilihat hubungan satu dengan yang lain, sehingga berakhir pada satu tujuan yang jelas. Munandar (dalam Piliang et al, 2014) menyatakan bahwa kreativitas merupakan hasil interaksi individu dengan lingkungannya, maka tampak jelas bahwa kreativitas individu sangat ditentukan oleh dorongan atau motivasi dari dalam diri dan lingkungannya. Hal-hal yang telah disebutkan sebelum ini nantinya akan berhubungan dan berpengaruh terhadap hasil belajar siswa.

Menurut Ramadhan et al (2018) model pembelajaran yang inovatif mampu meningkatkan hasil belajar peserta didik. Proses pembelajaran bahasa Indonesia di lingkungan merupakan salah satu cara mengembangkan inovasi siswa dengan berkolabirasi dengan lingkungan yang ada disekitar mereka. Oleh karena itu, proses pembelajaran pada lingkungan dapat diterapkan dalam pembelajaran bahasa Indonesia. Ramadhan et al (2019) mengungkapkan bahwa penggunaan tema lingkungan dalam pembelajaran yang berbasis teks dapat memicu minat siswa belajar bahasa dan secara implisit mampu meningkatkan pengetahuan siswa mengenai lingkungan.

Berdasarkan angket yang penulis sebarkan mengenai "Pentingnya Lingkungan dalam Pembelajaran Bahasa Indonesia" kepada anggota TNI, Polri, mahasiswa Universitas Negeri Padang, mahasiswa Universitas Andalas, mahasiswa STKIP PGRI, mahasiswa STAI YAPTIP, mahasiswa Stikes Farmasi Padang, mahasiswa Stikes Syedza Saintika, mahasiswa Universitas Syiah Kuala. Dari jumlah keseluruhan 32 responden yang ikut serta mengisi angket tersebut lebih dominan perempuan 25 responden dan laki-laki 7 responden dengan persentase $78,1 \%$ perempuan, 21,9\% laki-laki. Hasil data dari persentase angket yang telah dilakukan melalui google form tersebut dapat dilihat sebagai berikut.

Pertanyaan pertama, "memberikan materi lingkungan dalam pembelajaran bahasa Indonesia berupa teks narasi merupakan salah satu upaya membangun kecerdasan ekologis" 46,9\% menyatakan sangat setuju, 53,1\% menyatakan setuju, $0 \%$ menyatakan kurang setuju, dan 0\% menyatakan tidak setuju. Pertanyaan kedua, "mengembangkan suatu karya sastra dengan mengamati lingkungan sekitar" 59,4\% menyatakan sangat setuju, 40,6\% menyatakan setuju, $0 \%$ menyatakan kurang setuju, dan $0 \%$ menyatakan tidak setuju. Pertanyaan ketiga, "menjadikan lingkungan sebagai inspirasi dalam mengembangkan sebuah karya sastra" 59,4\% menyatakan sangat setuju, 40,6\% menyatakan setuju, 0\% menyatakan kurang setuju, dan $0 \%$ menyatakan tidak setuju. Pertanyaan keempat, "dapat mengembangkan sebuah puisi 
dengan mengamati lingkungan sekitar" 43,8\% menyatakan sangat setuju, 53,1\% menyatakan setuju, 3,1\% menyatakan kurang setuju, dan $0 \%$ menyatakan tidak setuju. Pertanyaan kelima, "mengamati objek-objek unik untuk mendapatkan hal menarik dalam pembuatan cerpen" 59,4\% menyatakan sangat setuju, 37,5\% menyatakan setuju, 3,1\% menyatakan kurang setuju, dan 0\% menyatakan tidak setuju. Pertanyaan keenam, "semua karya sastra 'cerita rakyat' menggambarkan kehidupan sosial masyarakat" 59,4\% menyatakan sangat setuju, 28,1\% menyatakan setuju, $12,5 \%$ menyatakan kurang setuju, dan $0 \%$ menyatakan tidak setuju. Pertanyaan ketujuh, "cerita rakyat "Timun Mas" berkaitan dengan lingkungan dalam buku bahasa Indonesia" 34,4\% menyatakan sangat setuju, 56,3\% menyatakan setuju, 9,4\% menyatakan kurang setuju, dan $0 \%$ menyatakan tidak setuju. Pertanyaan kedelapan, "lingkungan secara langsung atau tidak langsung dapat mengembangkan pola pikir, bertindak. berpilaku sehat secara fisik, dan mental dalam kehidupan sehari-hari" 65,6\% menyatakan sangat setuju, 31,3\% menyatakan setuju, 3,1\% menyatakan kurang setuju, dan $0 \%$ menyatakan tidak setuju. Pertanyaan kesembilan, "lingkungan dalam pembelajaran bahasa indonesia dapat diterapkan dalam kehidupan sehari-hari" 53,1\% menyatakan sangat setuju, 46,9\% menyatakan setuju, $0 \%$ menyatakan kurang setuju, dan $0 \%$ menyatakan tidak setuju. Pertanyaan kesepuluh, "lingkungan sangat penting dalam pembelajaran bahasa indonesia" $65,6 \%$ menyatakan sangat setuju, 34,4\% menyatakan setuju, $0 \%$ menyatakan kurang setuju, dan $0 \%$ menyatakan tidak setuju.

Dari hasil penyebaran angket yang telah dilakukan, dapat penulis simpulkan bahwa lingkungan memiliki hubungan dengan pembelajaran bahasa Indonesia. Hal ini dibuktikan oleh responden yang terdiri atas pelajar dan umum, yang menganggap bahwa lingkungan merupakan suatu hal yang penting dan memiliki hubungan dalam pembelajaran bahasa Indonesia. Menurut penulis, pemahaman masyarakat tentang hubungan lingkungan dengan pembelajaran bahasa Indonesia dikategorikan baik. Dengan demikian, lingkungan akan membantu siswa meningkatkan cara berpikir kreatif dan logis dalam pembelajaran bahasa Indonesia. 


\section{DAFTAR PUSTAKA}

Ira Guci, R Syahrul, Nursaid Nursaid. (2018). Korelasi Penguasaan Kosakata Bidang Lingkungan Hidup Dengan Menulis Karangan Argumentasi Tentang Lingkungan Hidup. Jurnal Pendidikan Bahasa dan Sastra Indonesia, Vol. 5 No. 2 September 2016; Seri B 169-174.

Piliang, Wilda S. H., Atmazaki, dan Syahrul Ramadhan. (2014). Kontribusi Kemampuan Apresiasi Sastra dan Berpikir Kreatif terhadap Keterampilan Bermain Drama pada Siswa Kelas XII IPS SMA Negeri 2 Rengat Kabupaten Indragiri Hulu. Jurnal Bahasa, Sastra dan Pembelajaran, 2(2), 75-87.

Putri, Diana dan Syahrul R. (2019). Korelasi Keterampilan Membaca Pemahaman dan Keterampilan Menulis Teks Laporan Hasil Observasi Siswa Kelas VII SMP Negeri 4 Pariaman. Jurnal Pendidikan Bahasa dan Sastra Indonesia, 8(1), seri A 62-69.

Ramadhan, S., Elfia Sukma, dan Vivi Indriyani. (2019). Environmental Education and Disaster Mitigation Through Language Learning. IOP Conference Series: Earth and Environmental Science, 314, p. 1-9.

Ramadhan, S., Elfia Sukma, dan Vivi Indriyani. (2019). Persepsi Guru terhadap Penggunaan Bahan Ajar Bahasa Indonesia dengan Perangkat Seluler dan Aplikasi Edmodo. Seminar Internasional Riksa Bahasa.

Ramadhan, S., Yasnur Asri, dan Vivi Indriyani . (2018). Learning Module Design Writing Argumentative Text Based Problem-Based Learning. Advances in Social Science, Education and Humanities Research, Vol 263: 194-200.

Sukma, Elfia. (2012). Pembelajaran Sastra yang Integratif Berbasis Kompetensi. International Conference on Languages and Arts, Halaman 432-436.

Sukma E, dan VP Azrianti. (2020). Instilling Positive Characters in Students Using Folker in the Macromedia Application. Advances in Social Science, Education and Humanities Research, Volume 485.

Oemar Hamalik. (2004). Proses Belajar Mengajar. Jakarta: Bumi Aksara.

Wilda Srihastuty Handayani Piliang, Atmazaki, Syahrul R. (2014). Kontribusi Kemampuan Apresiasi Sastra Dan Berpikir Kreatif Terhadap Keterampilan Bermain Drama Pada Siswa Kelas XII IPS SMA Negeri 2 Rengat Kabupaten Indragiri Hulu. Jurnal Bahasa, Sastra dan Pembelajaran, Vol. 2 No. 2, Juni 2014. 
Zulhafizh, Atmazaki, Syahrul R. (2013). Kontribusi Sikap dan Motivasi Belajar Siswa Terhadap Hasil Belajar Bahasa Indonesia. Jurnal Bahasa, Sastra dan Pembelajaran, Vol. 1 No. 2, Juni 2013. 